\title{
Analysis of expression of GAPDH gene in Solanum lycopersicum L. infected with Tomato torrado virus (ToTV)
}

\author{
Analiza ekspresji genu GAPDH w Solanum lycopersicum L. \\ podczas infekcji wirusem nekrozy pomidora - ToTV
}

\author{
Przemysław Wieczorek, Marta Budziszewska, Aleksandra Obrępalska-Stęplowska
}

\begin{abstract}
Summary
Real-time PCR (polymerase chain reaction) is a method commonly used for analysis of genes expression. However, accurate interpretation of real-time PCR results needs additional normalization step, where the expression level of analyzed gene is corrected to the actual amount of total RNA taken for the analysis. As a normalizer any gene can be used, provided its expression is stable during the experiment. GAPDH (glyceraldehyde 3-phosphate dehydrogenase) is one of candidates that might be used as a reference gene for normalization of real-time PCR. Here we indicated a high identity of GAPDH mRNA sequence isolated from ten varieties of tomato (Solanum lycopersicum). Moreover, we reported here, that expression of the gene was rather unstable in tomato during Tomato torrado virus infection (ToTV).
\end{abstract}

Key words: Tomato torrado virus, real-time PCR, reference gene

\section{Streszczenie}

Real-time PCR (polymerase chain reaction) prowadzona w czasie rzeczywistym łańcuchowa reakcja polimerazy jest jedną z technik umożliwiających ocenę zmian w poziomie ekspresji genów. Jednakże poprawna interpretacja wyników uzyskanych tą metodą wymaga normalizacji, co oznacza, że poziom transkryptu analizowanego genu należy zawsze odnosić do poziomu transkryptu genu referencyjnego, którego ekspresja powinna być stała w warunkach eksperymentu. Jednym z genów, którego transkrypt jest powszechnie stosowanym do normalizacji w real-time PCR jest mRNA dehydrogenazy aldehydu 3-fosfoglicerynowego (GAPDH glyceraldehyde 3-phosphate dehydrogenase). Wyniki prowadzonych prac wskazują na wysoki poziom podobieństwa sekwencji GAPDH u badanych odmian pomidora (Solanum lycopersicum), co umożliwiło zaprojektowanie uniwersalnej pary starterów do real-time PCR. Analiza ekspresji genu GAPDH przeprowadzona na podstawie obliczeń wykonanych z wykorzystaniem algorytmów geNorm, Normfinfder, BestKeeper oraz metodą porównania $\Delta \mathrm{Ct}$, wskazuje na wahania poziomu GAPDH w S. lycopersicum podczas zakażenia ToTV.

Słowa kluczowe: wirus nekrozy pomidora, real-time PCR, geny referencyjne

Instytut Ochrony Roślin - Państwowy Instytut Badawczy

Międzyzakładowa Pracownia Biologii Molekularnej

Władysława Węgorka 20, 60-318 Poznań

P.Wieczorek@iorpib.poznan.pl 


\section{Wstęp / Introduction}

Patogenezie spowodowanej zakażeniem grzybami, bakteriami oraz wirusami, w tym wywołanej obecnością wirusa nekrozy pomidora (Tomato torrado virus, ToTV) towarzyszą zmiany w ekspresji genów białek obronnych w komórkach gospodarza, wśród nich białek związanych z patogenezą (PR - pathogenesis related) (Wang i wsp. 2009). Istnieje wiele metod umożliwiających określenie zakresu zmian w poziomie ekspresji genów kodujących te białka. Jedną z nich jest łańcuchowa reakcja polimerazy prowadzona w czasie rzeczywistym (real-time PCR polymerase chain reaction) (Huggett i wsp. 2006). W podejściu tym istotne jest przeprowadzenie normalizacji uzyskanych danych, co oznacza, że poziom ekspresji genu badanego podczas eksperymentu należy zawsze analizować $\mathrm{w}$ odniesieniu do poziomu ekspresji genu referencyjnego, która w rozpatrywanych warunkach doświadczalnych powinna być możliwie jak najbardziej stabilna. Powszechnie stosowane geny referencyjne to: $\beta$-aktyna, czynnik elongacyjny EF $1 \alpha, 18 \mathrm{~S}$ rRNA (Perez i wsp. 2008). Jednym $z$ nich jest również gen dehydrogenazy aldehydu 3-fosfoglicerynowego (GAPDH - glyceraldehyde 3-phosphate dehydrogenase). Enzym ten bierze udział w glikolizie, przekształcając aldehyd 3-fosfoglicerynowy w 1,3-bisfosfoglicerynian. Dane literaturowe wskazują jednakże, iż geny referencyjne często pod wpływem warunków prowadzonego doświadczenia, a także etapu rozwoju rośliny czy rodzaju tkanki wykorzystanej do analiz, wykazują zmienny poziom swojej ekspresji (Paolacci i wsp. 2009). Stąd istotne jest wskazanie najbardziej stabilnego wśród nich $\mathrm{w}$ analizowanym kontekście (gospodarz, patogen, zastosowane warunki zewnętrzne, w tym termiczne, eksperymentu).

Celem pracy było porównanie sekwencji nukleotydów mRNA genu GAPDH dziesięciu odmian pomidora oraz ustalenie poziomu ekspresji tego genu u pomidorów zakażonych wirusem nekrozy pomidora (ToTV).

\section{Materiały i metody / Materials and methods}

Materiał badawczy stanowiło 10 odmian pomidora: Atol, Beta Lux, Babinicz, Grace, Koneser, Krakus, Krezus, Malinowy Ożarowski, Money Maker oraz Rumba Ożarowska, z których izolowano całkowity RNA (ribonucleic acid, kwas rybonukleinowy) wykorzystując odczynnik TriReagent (Life Technologies). Pozostałości genomowego DNA (deoxyribonucleic acid, kwasu deoksyrybonukleinowego) w uzyskanym preparacie RNA trawiono DNazą (Thermo Scientific), a następnie RNA reizolowano wykorzystując TriReagent (Life Technologies), wytrącano izopropanolem i zawieszano w 20-50 $\mu$ l wody. Jakość RNA określano metodą elektroforezy w żelu agarozowym, a stężenie RNA za pomocą spektrofotometru NanoDrop ND-1000 (Theromo Scientific).

$2 \mu \mathrm{g}$ RNA wykorzystano następnie do syntezy cDNA. Reakcję prowadzono w obecności losowych heksanukleotydów (ang. random primers) 5 NNN NNN3` (Thermo Scientific) oraz 200U odwrotnej transkryptazy RevertAid Reverse Transcriptase (Thermo Scientific). Syntezę cDNA prowadzono w $20 \mu \mathrm{l}$ mieszaniny reakcyjnej w temperaturze $42^{\circ} \mathrm{C}$ przez 60 minut, po czym preparat cDNA rozcieńczano 1,5× wodą (końcowe stężenie cDNA około $40 \mathrm{ng} / \mu \mathrm{l})$.

Zdeponowane w Banku Genów pełne sekwencje mRNA genu GAPDH Solanum lycopersicum (numery akcesyjne: NM_001247874.1, U97257.1, U93208.1) porównywano ze sobą za pomocą algorytmu ClustalW wskazując regiony silnie konserwowane w mRNA GAPDH. Na tej podstawie wyznaczono miejsca hybrydyzacji starterów zdegenerowanych (tab. 1) wykorzystanych następnie w reakcji PCR. Reakcję PCR prowadzono w obecności starterów SlGapdhQ1 oraz SlGapdhQ2 (tab. 1) $(0,5 \mu \mathrm{M})$ oraz $1 \mathrm{U}$ polimerazy Allegro Taq DNA Polymerase (Novazym) z wykorzystaniem $1 \mu \mathrm{l}$ cDNA w $10 \mu \mathrm{l}$ końcowej objętości mieszaniny reakcyjnej w następujących warunkach: $95^{\circ} \mathrm{C} 3$ minuty, a następnie 35 cykli: $95^{\circ} \mathrm{C} \quad 30$ sekund, $55^{\circ} \mathrm{C} \quad 30$ sekund, $72^{\circ} \mathrm{C}$ 60 sekund, po czym $72^{\circ} \mathrm{C} 10$ minut. Produkty reakcji PCR ligowano $\mathrm{z}$ wektorem pGEM-T Easy (Promega). Zrekombinowanymi wektorami transformowano kompetentne komórki Escherichia coli szczepu TOP10 (Life Technologies). Z transformantów E. coli, zawierających żądany insert GAPDH, izolowano plazmidowy DNA (Macherey-Nagel) i sekwencjonowano (CBDNA, Poznań). Analizę porównawczą sekwencji fragmentu mRNA GAPDH dziesięciu odmian pomidora przeprowadzono z wykorzystaniem programu ClustalW. Analizę zależności filogenetycznych GAPDH wykonano w oparciu o metodę maksymalnego prawdopodobieństwa (ang. Maximum Likelihood) wykorzystując oprogramowanie MEGA 5.10. $\mathrm{Na}$ tej podstawie wskazano wysoce konserwowane fragmenty sekwencji mRNA GAPDH, do których zaprojektowano odpowiednie startery do reakcji real-time PCR.

Tabela 1. Startery wykorzystane do reakcji PCR oraz PCR w czasie rzeczywistym

Table 1. Primers used in PCR and real-time PCR assay

\begin{tabular}{|c|c|c|c|}
\hline $\begin{array}{c}\text { Nazwa startera } \\
\text { Primers` ID }\end{array}$ & $\begin{array}{c}\text { Sekwencja } 5^{\prime} \rightarrow 3^{\prime} \\
\text { Sequence } 5 \rightarrow 3^{\prime}\end{array}$ & $\begin{array}{l}\text { Temperatura hybrydyzacji } \\
\text { Annealing temperature }\end{array}$ & $\begin{array}{l}\text { Długość produktu } \\
\text { Produkt length }\end{array}$ \\
\hline SlGapdhQ1 & ATGTTGAACTmGTyGCAGTG & \multirow{2}{*}{$55^{\circ} \mathrm{C}$} & \multirow{2}{*}{$530 \mathrm{pz} / \mathrm{bp}$} \\
\hline SlGapdhQ2 & GTTGAAyGAAGCAGCTCTTC & & \\
\hline SlGAPDHa & CArTGGAAGCATCATGAGCT & \multirow{2}{*}{$55^{\circ} \mathrm{C}$} & \multirow{2}{*}{$196 \mathrm{pz} / \mathrm{bp}$} \\
\hline SlGAPDHb & TTCTTGGCrCCACCCTTCAA & & \\
\hline
\end{tabular}


W celu ustalenia poziomu ekspresji GAPDH w S. lycopersicum, w warunkach stresu biotycznego, tzn. podczas infekcji wirusem ToTV, przeprowadzono doświadczenie oparte na reakcji PCR prowadzonej w czasie rzeczywistym. $Z$ roślin pomidora odmiany Grace infekowanych ToTV i wykazujących wyraźne objawy zakażenia, izolowano RNA i przygotowano cDNA (według procedury opisanej powyżej). Reakcję real-time PCR prowadzono w obecności starterów SlGAPDHa oraz SIGAPDHb (tab. 1) $(0,5 \mu \mathrm{M})$, barwnika EvaGreen (1×, Biotium), $1 \mathrm{U}$ polimerazy Allegro Taq DNA Polymerase (Novazym) wykorzystując $1 \mu \mathrm{l}$ cDNA. Mieszaninę reakcyjną inkubowano $\mathrm{w} 95^{\circ} \mathrm{C}$ przez 3 minuty, a następnie przeprowadzono 40 cykli: $95^{\circ} \mathrm{C} 20$ sekund, $55^{\circ} \mathrm{C} 20$ sekund, $72^{\circ} \mathrm{C} 20$ sekund. Ocena poziomu ekspresji genu GAPDH $\mathrm{u}$ roślin infekowanych ToTV oraz u roślin zdrowych została przeprowadzona metodami: geNorm, Normfinder, BestKeeper oraz metodą porównania $\Delta \mathrm{Ct}$ (Perez i wsp. 2008).

\section{Wyniki i dyskusja / Results and discussion}

Wśród wielu metod umożliwiających badanie zmian w ekspresji genów w komórce, PCR w czasie rzeczywistym jest techniką charakteryzującą się wysoką czułością oraz powtarzalnością (Wong i Medrano 2005). W zależności od zakładanego celu eksperymentu, PCR w czasie rzeczywistym może mieć charakter analizy jakościowej lub ilościowej. W tym drugim podejściu eksperymentalnym zmiany $\mathrm{w}$ ilości matrycy (DNA lub RNA właściwie cDNA) można określać metodą analizy bezwzględnej lub względnej. Jak w każdym eksperymencie związanym $\mathrm{z}$ określeniem różnic $\mathrm{w}$ ekspresji genów, niezależnie czy matrycę stanowi mRNA komórkowy czy RNA będący materiałem genetycznym niektórych wirusów, zmiany ilości badanej matrycy należy każdorazowo odnosić do poziomu genu (genów), którego ekspresja w rozpatrywanych warunkach doświadczenia jest bezwzględnie stała (Guénin i wsp. 2009). Proces ten, określany jako normalizacja, gwarantuje poprawną interpretację wyników eksperymentu w sytuacji, gdy materiał badany, np. RNA, pochodzi z dwóch lub więcej źródeł. Normalizacja stanowi niezbędne potwierdzenie wykorzysania identycznej ilości materiału badanego do kompara- tywnych analiz (Pfaffl 2010). W doświadczeniach opartych na PCR w czasie rzeczywistym normalizację przeprowadza się wykorzystując ekspresję genów referencyjnych, zakładając, że jest stała i nie podlega wpływowi zmiennych warunków doświadczenia. Jak wskazują dane literaturowe, nie można mówić o uniwersalnym genie referencyjnym (Klie i Debener 2011). Spośród puli genówkandydatów należy wybrać taki, który w danych warunkach eksperymentalnych jest najlepszym normalizatorem i tylko względem takiego przeprowadzać należy interpretację wyników.

W prezentowanych badaniach przeprowadzono analizę sekwencji nukleotydów fragmentu genu dehydrogenazy aldehydu 3-fosfoglicerynowego (GAPDH), jednego z genów referencyjnych powszechnie wykorzystywanych do normalizacji wyników real-time PCR. Zdegenerowane startery, zaprojektowane na podstawie danych $\mathrm{z}$ Banku Genów, umożliwiły wydajną amplifikację 520-nukleotydowego fragmentu cDNA genu GAPDH wszystkich dziesięciu analizowanych odmian pomidora (rys. 1). Taka długość produktu PCR jest wystarczająca dla wyznaczenia regionów konserwowanych w mRNA GAPDH i zaprojektowania na ich podstawie wewnętrznych starterów do przeprowadzenia reakcji PCR w czasie rzeczywistym, gdzie długość amplikonu powinna zawierać się $\mathrm{W}$ przedziale 80-300 pz. Analiza fragmentu sekwencji tego genu

Tabela 2. Wyniki analiz poziomu ekspresji genu GAPDH w $S$. $l y$ copersicum odmiany Grace bardzo podatnej na infekcję ToTV. Wynik podany został w jednostkach względnej ekspresji (jwe.)

Table 2. Estimated expression of GAPDH in S. lycopersicum (variety Grace) highly susceptible to ToTV. Results are indicated in relative expression units (reu.)

\begin{tabular}{l|c}
\hline \multicolumn{1}{c|}{$\begin{array}{c}\text { Metoda } \\
\text { Method used }\end{array}$} & $\begin{array}{c}\text { Wynik [jwe.] } \\
\text { Results [reu.] }\end{array}$ \\
\hline geNorm & 0,511 \\
\hline normFinder & 0,359 \\
\hline BestKeeper & 0,68 \\
\hline$\Delta \mathrm{Ct}$ & 0,889 \\
\hline
\end{tabular}

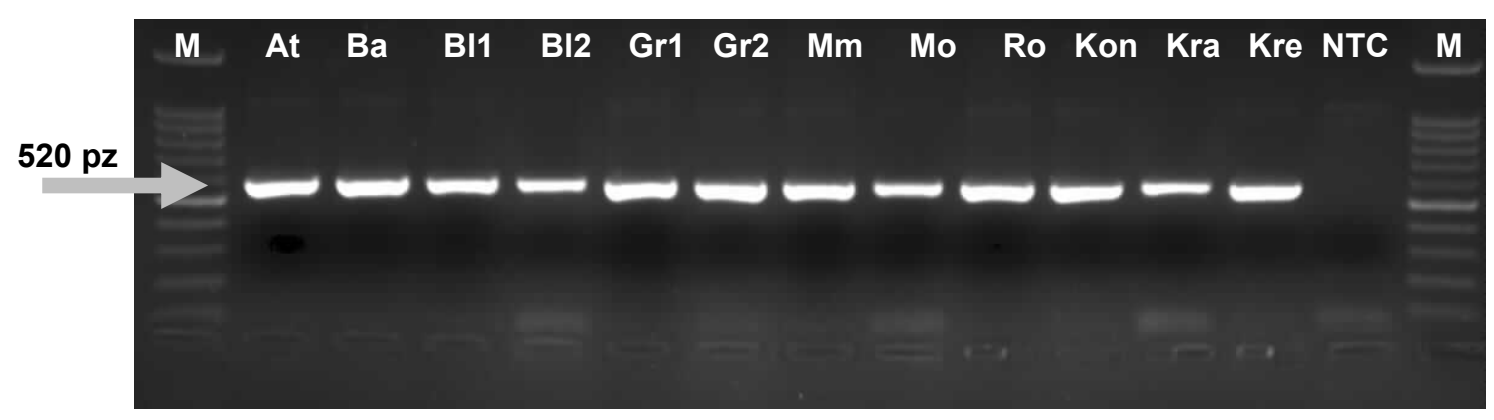

Rys. 1. Wynik rozdziału produktów reakcji PCR prowadzonej z wykorzystaniem starterów zdegenerowanych SlGapdhQ1 oraz SlGapdhQ2. M - marker masy DNA, S. lycopersicum odmian: At - Atol, Ba - Babinicz, Bl - Beta Lux, Gr - Grace, Mm Money Maker, Mo - Malinowy Ożarowski, Ro - Rumba Ożarowska, Kon - Koneser, Kra - Krakus, Kre - Krezus

Fig. 1. Electrophoresis of PCR products obtained using S1GapdhQ1 and S1GapdhQ2 primers. M - DNA mass ladder; At, Ba, B11, B12, Gr1, Gr2, Mm, Mo, Ro, Kon, Kra, Kre - tomato varietes; NTC - no template control 

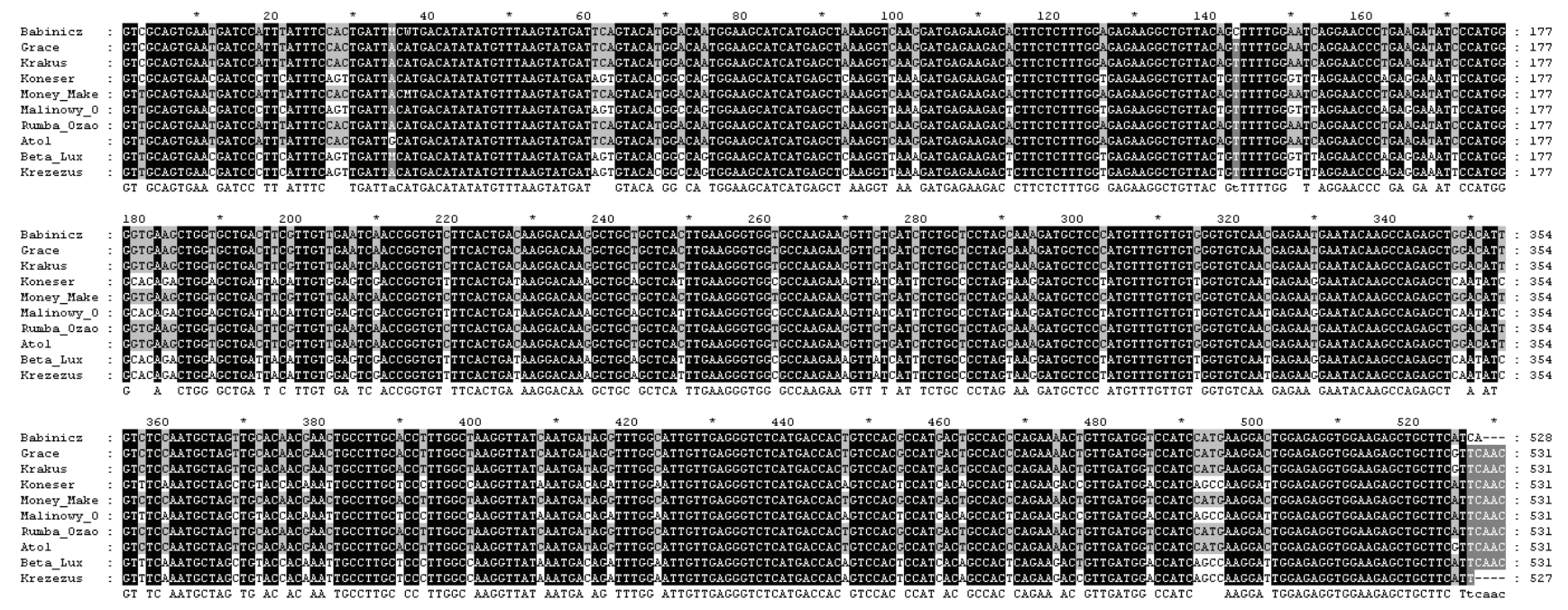

Rys. 2. Przyrównanie wielosekwencyjne fragmentu mRNA GAPDH u dziesięciu analizowanych odmian S. lycopersicum

Fig. 2. Multiple sequence alignmenet of partial nucleotide sequence of GAPDH mRNA from ten analyzed $S$. lycopersicum varieties

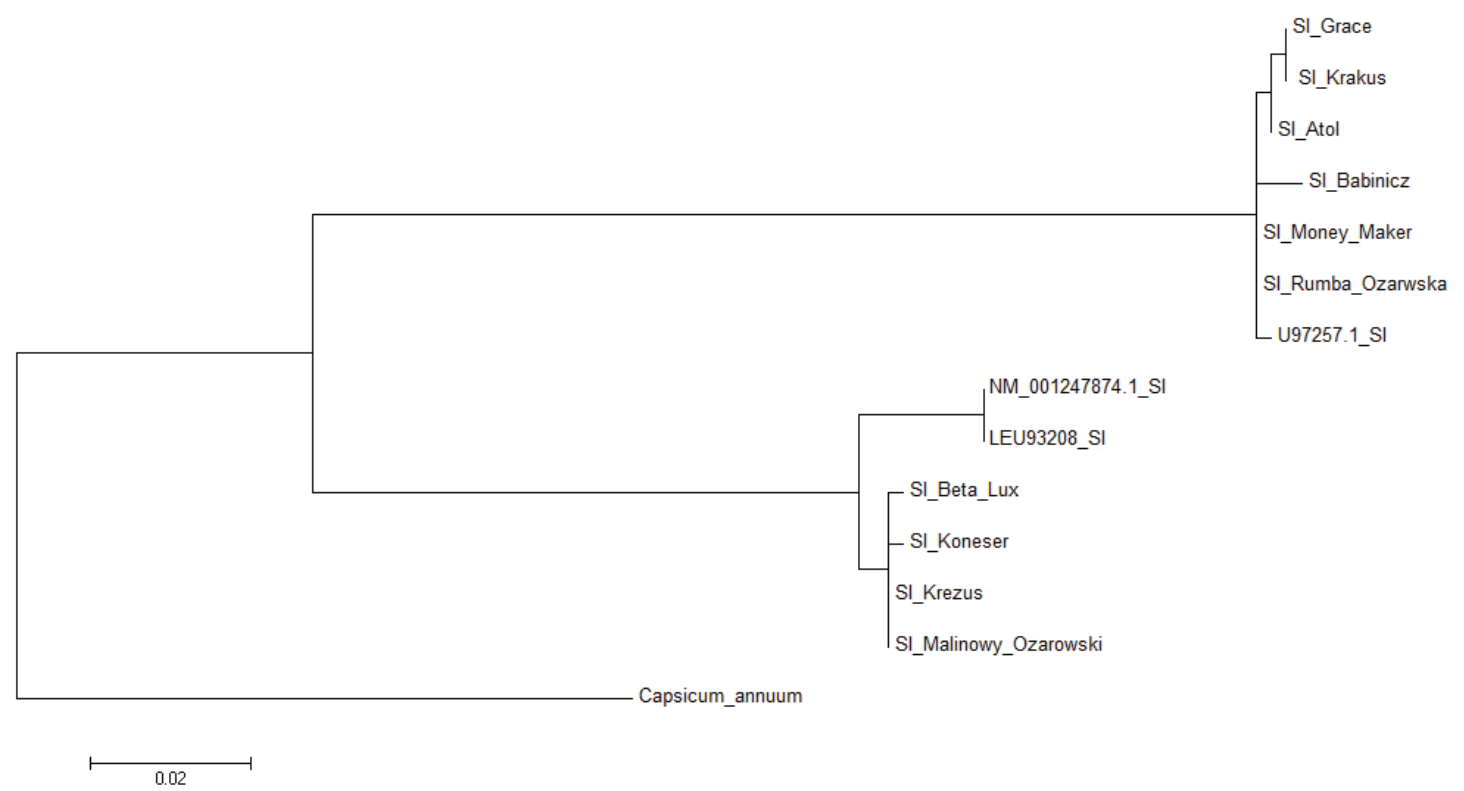

Rys. 3. Dendrogram obrazujący zależności filogenetyczne dla fragmentu genu GAPDH analizowanego u dziesięciu odmian $S$. lycopersicum oraz Capsicum annuum (grupa odniesienia). Drzewo skonstruowano w oparciu o metodę maksymalnego prawdopodobieństwa (ML)

Fig. 3. Phylogenic analysis of GAPDH partial sequence isolated from ten varieties of $S$. lycopersicum and Capsicum annuum (outgroup). The dendrogram was created on the basis of maximum likelihood (ML) algorithm

wskazała jego wysoki poziom podobieństwa $\mathrm{u}$ analizowanych odmian $S$. lycopersicum (rys. 2, 3), co pozwoliło na zaprojektowanie starterów, które wykorzystano do ustalenia metodą real-time PCR poziomu ekspresji genu GAPDH w pomidorach infekowanych wirusem ToTV (tab. 1). W celu określenia poziomu ekspresji GAPDH w roślinach zdrowych oraz infekowanych ToTV, dane uzyskane z eksperymentów real-time PCR poddano analizie bioinformatycznej, do czego wykorzystano cztery niezależne metody: geNorm, normFinder, BestKeeper oraz porównawczą analizę $\Delta \mathrm{C}_{\mathrm{T}}$, a zasadność wykorzystania w tym celu kilku algorytmów obliczeniowych miła na celu eliminację wyników fałszywie pozytywnych. Poziom ekspresji GAPDH w roślinach infekowanych wirusem ToTV odnoszono do poziomu ekspresji tego genu w roślinach zdrowych (tu wyjściowy poziom ekspresji równy jest wartości „1”). Dane obliczeniowe uzyskane za pomocą wyżej wymienionych metod wskazują, że w obecności ToTV ekspresja GAPDH spada, co zostaje wyrażone poprzez wartości współczynnika jednostek względnej ekspresji, który jest w każdym przypadku mniejszy od wartości wyjściowej (tab. 2) i zawiera się w przedziale od 0,359 do 0,889 . Wyniki przeprowadzonych analiz wskazały, że ekspresja GAPDH zmienia się w warunkach stresu biotycznego, tj. podczas infekcji wirusem ToTV. 


\section{Wnioski / Conclusions}

1. Sekwencja mRNA dziesięciu analizowanych odmian S. lycopersicum jest wysoce konserwowana. Zmiany w sekwencji nukleotydów tego genu związane są z obecnością pojedynczych substytucji, które determinują, pod tym względem, grupowanie badanych odmian pomidora w dwóch klastrach.

2. W analizowanych warunkach doświadczenia, to znaczy w obecności wirusa ToTV, ekspresja genu GAPDH u pomidora waha się $\mathrm{w}$ odniesieniu do roślin zdrowych. Sugeruje to, że do prac związanych z badaniem zmian w ekspresji genów należałoby wykorzystać sekwencję inną niż GAPDH.

Badania finansowano w ramach projektu NCN nr 2011/ N/NZ9/07131.

\section{Literatura / References}

Guénin S., Mauriat M., Pelloux J., Van Wuytswinkel O., Bellini C. 2009. Normalization of qRT-PCR data: the necessity of adopting a systematic, experimental conditions-specific, validation of references. J. Exp. Bot. 60: 487-493.

Huggett J., Dheda K., Bustin S.A. 2006. Normalization. p. 83-92. In: "Real-time PCR" (M.T. Dorak, ed.). Taylor and Francis Group, New York, 333 pp.

Klie M., Debener T. 2011. Identification of superior reference genes for data normalisation of expression studies via quantitative PCR in hybrid roses (Rosa hybrida). BMC Research Notes, 4, 518, DOI: 10.1186/1756-0500-4-518.

Paolacci A.R., Tanzarella O.A., Porceddu E., Ciaffi M. 2009. Identification and validation of reference genes for quantitative RT-PCR normalization in wheat. BMC Mol. Biol. 10 (1): 27, DOI: 10.1186/1471-2199-10-11.

Perez R., Tupac-Yupanqui I., Dunner S. 2008. Evaluation of suitable reference genes for gene expression studies in bovine muscular tissue. BMC Mol. Biol. 9: 79, DOI: 10.1186/1471-2199-9-79.

Pfaffl M.W. 2010. The ongoing evolution of qPCR. Methods 50: 215-216.

Wang X.J., Tang C.L., Zhang G., Li Y.C., Wang C.F., Liu B., Qu Z.P., Zhao J., Han Q.M., Huang L.L., Chen X.M., Kang Z.S. 2009. cDNA-AFLP analysis reveals differential gene expression in compatible interaction of wheat challenged with Puccinia striiformis f. sp. tritici. BMC Genomics 10: 289, DOI: 10.1186/1471-2164-10-289.

Wong M.L., Medrano J.F. 2005. Real-time PCR for mRNA quantitation. Biotechniques 39: 75-85. 